\title{
A new species of deep-water Holothuroidea (Echinodermata) of the genus Synallactes from off western Mexico
}

\author{
CLAUDE MASSIN ${ }^{1}$ and MICHEL E. HENDRICKX ${ }^{2}$ \\ ${ }^{1}$ Department of Recent Invertebrates, Royal Belgian Institute of Natural Sciences, Rue Vautier 29, Brussels, \\ B-1000, Belgium. E-mail: claude.massin@naturalsciences.be \\ ${ }^{2}$ Laboratorio de Invertebrados Bentónicos, Unidad Académica Mazatlán, Instituto de Ciencias del Mar y Limnología, \\ Universidad Nacional Autónoma de México, PO Box 811, Mazatlán, 82000, Sinaloa, México. \\ E-mail: michel@ola.icmyl.unam.mx
}

\begin{abstract}
SUMMARY: An undescribed species of Synallactes was collected during a deep-water benthic fauna survey off the Pacific coast of Mexico in the East Pacific, with the R/V El Puma. This new species differs from all the other known Synallactes by the presence of huge massive rods in the tube feet, some of them club-shaped. The later ossicle shape is unique among Holothuroidea. This is the first record of a Synallactes in the Gulf of California.
\end{abstract}

Keywords: Holothuroidea, Synallactes n. sp., club-shaped ossicles, deep water, East Pacific, Mexico.

RESUMEN: UNA NUEVA ESPECIE DE AGUAS PROFUNDAS DE HolothURoIdEA (ECHINODERMATA) DEL GÉNERo SYNALLACTES Del Pacífico mexicano. - Una especie de Synallactes no descrita ha sido recolectada durante un programa de estudio de la fauna bentónica de aguas profundas del Pacífico mexicano, en el Pacífico Este, por el B/O "El Puma". Esta nueva especie difiere de todas las especies de Synallactes conocidas por la presencia de barrotes muy largos y masivos en los pies ambulacrales, algunos en forma de clava. Esta forma de osículos es única dentro de los Holothuroidea. Esta especie nueva representa el primer registro del género para el golfo de California.

Palabras claves: Holothuroidea, Synallactes n. sp., osículos en forma de mazo, aguas profundas, Pacífico Este, México.

\section{INTRODUCTION}

The deep-water Holothuroidea of the East Pacific have been studied mainly by Ludwig (1893, 1894) and H.L. Clark (1913, 1920, 1923). In 1988, Maluf compiled the information on central part of the east Pacific holothuroids. This study includes four Synallactes species, viz S. aenigmae Ludwig, 1893, S. alexandri Ludwig, 1893, S. ishikawa f. ind. Mitsukuri, 1912 (now considered as a synonym of $S$. sagamiensis Augustin, 1908) and S. triplax H.L. Clark, 1920. Only $S$. ishikawa has been collected along the Mexican West coast (Parker, 1964), whereas no Synallactes are mentioned in the Gulf of California (Maluf and $\mathrm{Br}$ - usca, 2005). The family Synallactidae has been revised by Solís-Marín (2003), Solís-Marín and LaguardaFigueras (2004) and Solís-Marín (2005). Including a new species recently described for southern Africa (Thandar, 2008), 24 species of the genus Synallactes are recognized as valid. Moreover, Solís-Marín et al. (2005) and Honey-Escandón et al. (2008) compiled the echinoderm species in the Gulf of California and in western Mexico (excluding the Gulf). Both lists, based exclusively on records verified in Maria Elena Caso Muñoz's collections (Universidad Nacional Autónoma de México, Mexico D.F.) and in the Smithsonian Institution collections (Washington D.C.), include 55 species of Holothuroidea, but no species of Synallactes. 
During a deep-water benthic fauna survey off the Pacific coast of Mexico, in the East Pacific, material belonging to the genus Synallactes was dredged at $1030 \mathrm{~m}$ depth in the SW Gulf of California and is the object of the present paper.

\section{MATERIALS AND METHODS}

Acronyms and abbreviations. CTD: Conductivity, Temperature, Density. UNAM: Universidad Nacional Autónoma de México. EMU: Regional Collection of Invertebrates, Instituto de Ciencias del Mar y Limnología, UNAM. ICML-UNAM: Maria Elena Caso Muñoz's Collection, Instituto de Ciencias del Mar y Limnología, UNAM. IG-HOL: General Inventory, Holothuroidea Collection, Royal Belgian Institute of Natural Sciences. TL: Total length.

Samples of Holothuroidea were obtained at depths between 600 and $2250 \mathrm{~m}$ on the continental slope of the southern Gulf of California using a benthic sledge (2.35 $\mathrm{m}$ width, $0.9 \mathrm{~m}$ height) equipped with a modified shrimp net $(5.5 \mathrm{~cm}$ stretched mesh size). A total of 13 cruises were organized in the Gulf of California and along the west coast of Mexico, south of Banderas Bay, from 1989 to 2008. Positional coordinates for each sampling station were plotted using a GPS navigation system. Depth was measured with a digital recorder. Epibenthic water temperature and salinity were measured with a Seabird CTD, and dissolved oxygen content was measured with the Winkler method and with a probe attached to the CTD. Holothuroidea were fixed on board with a $4 \%$ formaldehyde sea water solution for a few days, washed with tap water and preserved in $70 \%$ ethanol.

\section{TAXONOMY}

Order ASPIDOCHIROTIDA Grube, 1840

Family SynallactidaE Ludwig, 1894 Genus Synallactes Ludwig, 1894 Synallactes virgulasolida $\mathrm{n}$. $\mathrm{sp}$. (Figs. 1-3)

Synallactes alexandri; Haney, 2004: 3, Appendix 1-4, Pl. 1, Figs. 1-2, Pl. 2, Figs. 1-4.

Type locality. TALUD VIII, Off SE Baja California, Station 16 (2524'26”N, 110³7'36”'W), 18/April/2005, three specimens (TL 50,60 and $85 \mathrm{~mm}$ ), benthic sledge, $1030 \mathrm{~m}$ depth.

Type material. Holotype in Mazatlán, Mexico (EMU-8608); paratype 1 in Brussels, Belgium (IG.31487-HOL 1506); paratype 2, Maria Elena Caso Muñoz's Collection, in Mexico DF, Mexico (ICML-UNAM 5.171.0).

Abiotic data. At the type locality, epibenthic water temperature and dissolved oxygen were, respectively, $5^{\circ} \mathrm{C}$ and $0.20 \mathrm{ml} \mathrm{O}_{2} / 1$. Bottom of fine black mud.
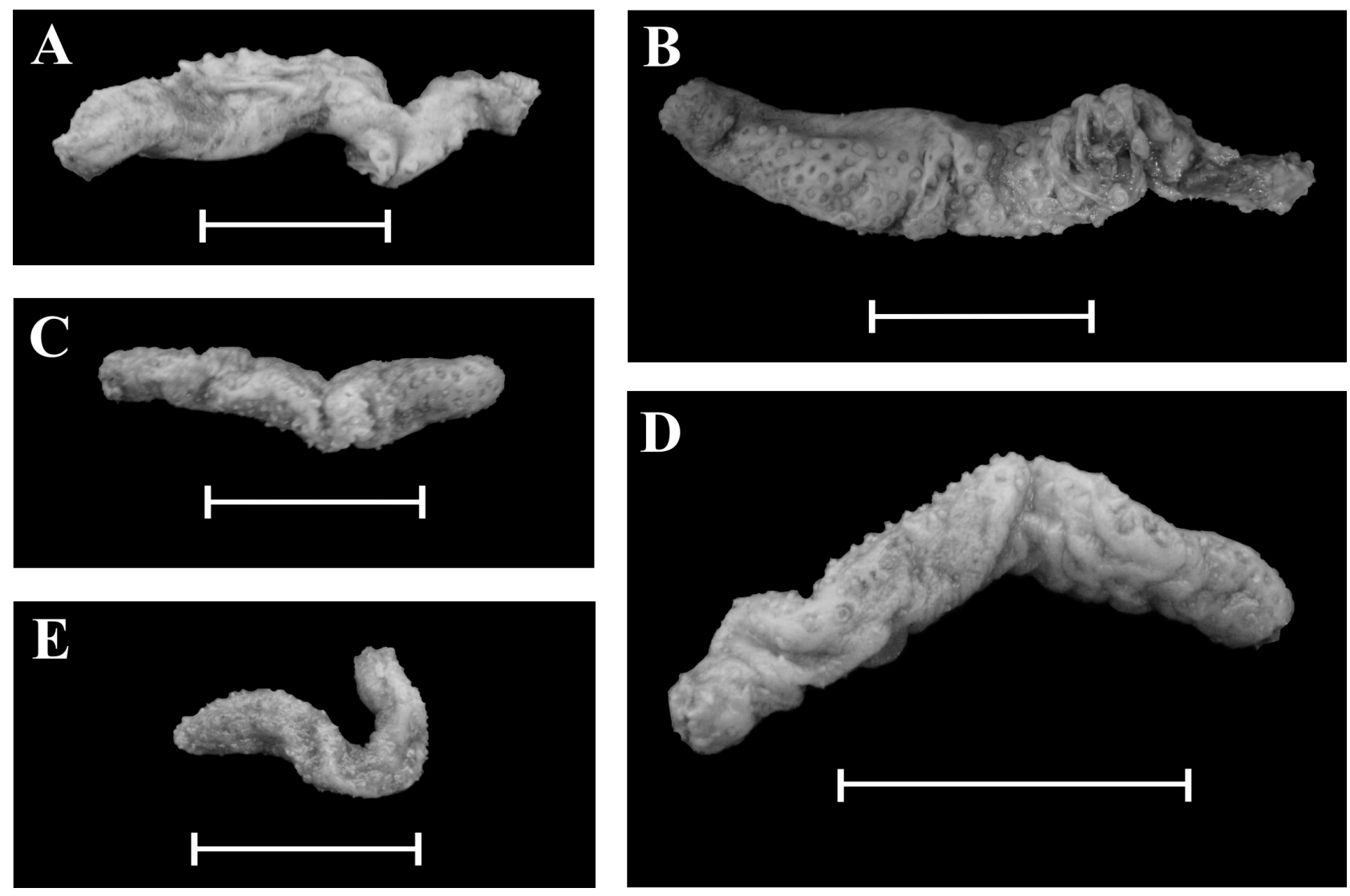

FIG. 1. - Synallactes virgulasolida $\mathrm{n}$. sp. A, dorsal view of the holotype; B, ventral view of the holotype; C, general view of paratype 1; D, lateral view of paratype $1 ; \mathrm{E}$, general view of paratype 2 . 


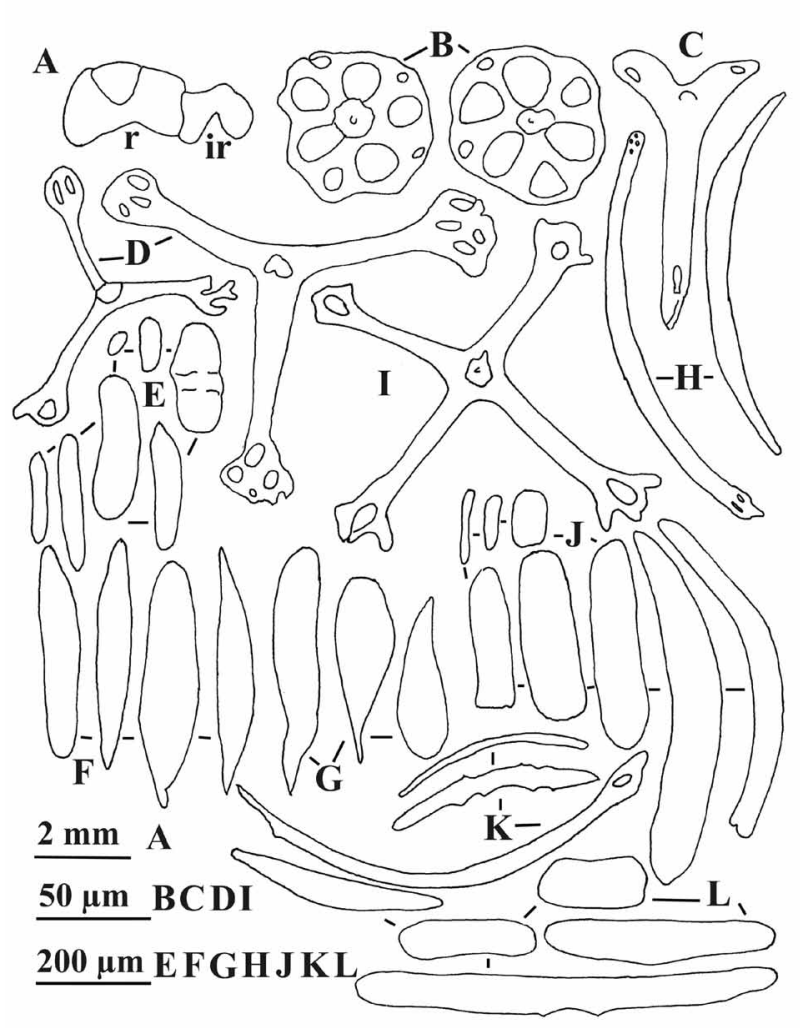

FIG. 2. - Synallactes virgulasolida $\mathrm{n}$. sp. A, calcareous ring paratype (r: radial piece; ir: interradial piece); B, tables of ventral body wall (holotype); C, table from ventral body wall, lateral view (holotype); D, cross-shaped ossicles from dorsal body wall (holotype); E, bean-shaped ossicles from ventral tube feet (holotype); F, massive rods of the ventral tube feet (holotype); G, club-shaped ossicles from ventral tube feet (holotype); $\mathrm{H}$, slender rods from the ventral tube feet (holotype); I, cross-shaped ossicles from ventral tube feet (holotype); J, massive rods from ventral tube feet (paratype 1); K, slender rods from ventral tube feet (paratype 1); L, massive rods from ventral tube feet (paratype 2).

Etymology. The name of the new species is a combination of the Latin words virgula meaning "rod" and solida meaning "massive". It refers to the huge massive rods from the tube feet.

External anatomy. Medium size holothurian, cylindrical, slightly tapering posteriorly (Fig. 1A, B, C, E). Body length 50, 60 and $85 \mathrm{~mm}$ with a diameter of 5, 10 and $13 \mathrm{~mm}$, respectively. In alcohol, body wall brownbeige with tube feet and tentacles yellow. Mouth ventral surrounded by 18-20 shield shaped tentacles. Tentacles surrounded (mainly dorsally) by a collar of very long papillae which have a hairy aspect because of the pillar of the cross-shaped ossicles protruding outside. Ventral tube feet very large (Fig. 1A, B, D), conical, aligned in 2-3 rows (Fig. 1B). One row of very large tube feet along the limit bivium/trivium (Fig. 1D). Dorsally, numerous cylindrical papillae, spread all over the bivium.

Internal anatomy. Calcareous ring well developed, massive (Fig. 2A) in the two small specimens; in

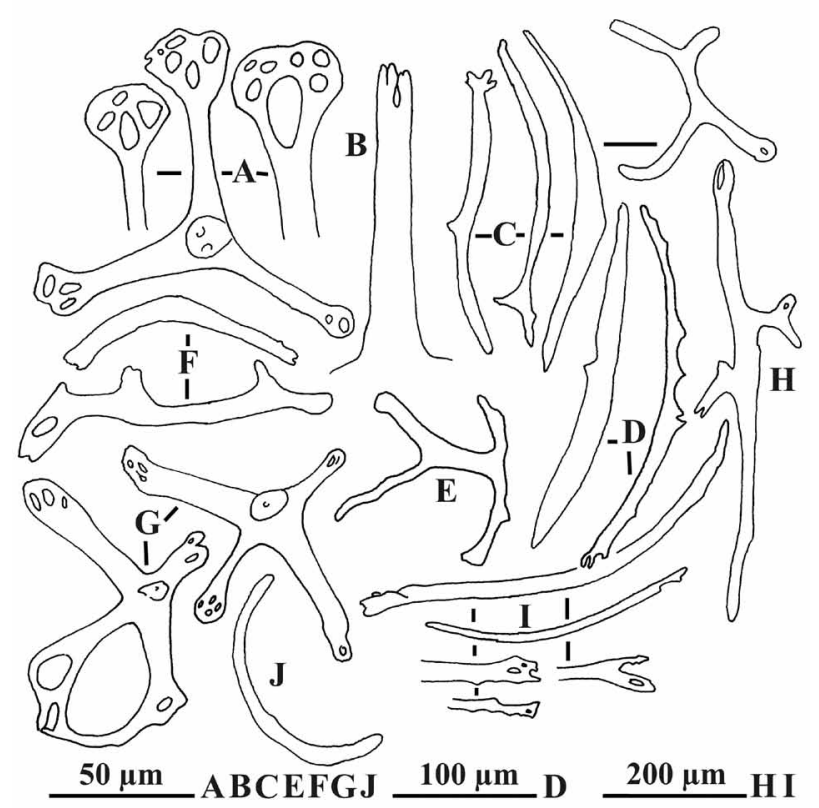

FIG. 3. - Synallactes virgulasolida n. sp. A, cross-shaped ossicles from dorsal papillae (holotype); B, central pillar of a cross-shaped ossicles from dorsal papillae (holotype); C, rods from dorsal papillae (holotype); D, E, F, H, rods of the tentacles (holotype); G, cross-shaped ossicles from the tentacles (holotype); I, J, rods of the tentacles (paratype 1).

the largest specimen the calcareous ring is very thin, translucent, made of a meshwork of tubules. No tentacle ampullae. Polian vesicle and madreporic plate not observed. Longitudinal muscles well developed, cylindrical.

Ossicles. In the ventral body wall, tables 70-80 $\mu \mathrm{m}$ across, perforated by 7-10 holes (Fig. 2B). One central pillar 105-120 $\mu \mathrm{m}$ high, perforated at the extremity and/or ending in a few short spines (Fig. 2C). On the dorsal body wall a few cross shaped ossicles (Fig. 2D), generally with one central pillar and three arms perforated at their extremities. These cross-shaped ossicles are 120-150 $\mu \mathrm{m}$ across. In the ventral and lateral tube feet of the holotype huge, massive, smooth rods going from granules (80-200 $\mu \mathrm{m}$ long) (Fig. 2E) to massive rods (Fig. 2F) up to $750 \mu \mathrm{m}$ long. Some of these massive rods are club-shaped (Fig. 2G). In the paratypes same massive rods (Fig. 2J, L) but no club-shaped ossicles were observed. Among the massive rods, long slender rods with perforated extremities (Fig. 2H). Slender rods of the paratype are similar to the one of the holotype (Fig. 2K). In the ventral tube feet, cross-shaped ossicles (Fig. 2I) are present. The end plate of the ventral and lateral tube feet is made of several plates which together measured $450 \mu \mathrm{m}$ across. The holes of the end plate are very irregular in size and form. In the dorsal papillae, cross-shaped ossicles with 3-4 arms (Fig. 3A, B) together with irregular rods 120-150 $\mu \mathrm{m}$ long (Fig. 3C). In the tentacles, rods (Fig. 
3D, E, F), and cross-shaped ossicles (Fig. 3G). Rods densely packed around the shaft of the tentacles, similar in the holotype and paratypes (Fig. 3I, J). They are irregular, 100-750 $\mu \mathrm{m}$ long, smooth or spiny, straight, curved or branched with forked or perforated extremities. A few cross-shaped ossicles located at the base of the tentacles. They are up to $130 \mu \mathrm{m}$ across with the end of the branches perforated by 2-6 holes. Some branches are fused at their extremities (Fig. 3G).

Remarks. The three specimens observed belong without any doubt to the family Synallactidae and the genus Synallactes, as defined by Solís-Marín (2003).

Synallactes virgulasolida $\mathrm{n}$. sp. is easy to separate from all the other Synallactes species by the presence in the ventral and lateral tube feet of massive granules growing up to smooth massive rods, some of them being club-shaped in the largest specimen (holotype). These club-shaped ossicles are up to now unique among sea cucumber ossicles. Granules and bean-shaped ossicles are well known in the genus Bohadschia (see Panning, 1944), in some specimens of Actinopyga such as A. mauritiana (Quoy and Gaimard, 1833) (see Cherbonnier, 1988: Fig. 2A), and in Neostichopus grammatus (H.L. Clark, 1923) (see Thandar, 1984: Fig. 40h). But all these granules are much smaller $(20-50 \mu \mathrm{m}$ long) than the ones of Synallactes virgulasolida $\mathrm{n}$. sp. Only some Orphnurgus, such as Orphnurgus glaber Walsh, 1891 (see Hansen, 1975: Fig. 13) have granules up to $450 \mu \mathrm{m}$ long.

S. virgulasolida shows affinities with the two Synallactes known from the Central East Pacific (Maluf, 1988), i.e. Synallactes alexandri Ludwig, 1893 and Synallactes aenigma Ludwig, 1893. S. virgulasolida has body wall tables very similar to those of $S$. alexandri (see Ludwig, 1894) and cross-shaped ossicles from the body wall very similar to those of $S$. aenigma (see Ludwig, 1894). Moreover, S. aenigma and S. virgulasolida have a similar distribution of the tube feet (Ludwig, 1894; H.L. Clark, 1920). Both authors also noted the possible absence of the calcareous ring in the studied specimens of $S$. aenigma. S. virgulasolida shows a reduction of the calcareous ring with growing size, which could result in its absence in very large specimens.

The S. alexandri mentioned by Haney (2004) shows in the tube feet numerous bean-shaped ossicles identical to those observed in S. virgulasolida. Neither Ludwig (1894) in his original description nor Solís-Marin (2003) in the redescription of the type material refer to the presence of these bean-shaped ossicles in the tube feet of $S$. alexandri. These ossicles are so large and so numerous that they cannot be overlooked. They are a good discriminant character which, up to now, has not been observed in any other Synallactes, included the species from South Africa recently described by SolísMarin (2005) and Thandar (2008).

We consider the specimen described by Haney (2004) to be a Synallactes virgulasolida and not a $S$. alexandri. Consequently, the distribution of S. virgulasolida is extended from the Gulf of California (Mexico) to California (USA), and its depth range is from 500 to $1030 \mathrm{~m}$.

S. virgulasolida shows an evolution of its ossicle assemblages with size, as observed in many other sea cucumbers (see among others Massin 1994; Massin et al. 2000). The appearance of club-shaped ossicles in large specimens could be interpreted as a discriminant character to erect a new species. DNA analysis will certainly help to solve this problem but the material collected was not preserved for such analysis (material in formalin). However, the club-shaped ossicles are derived from the bean-shaped ossicles and we do not observe a hiatus between the two kinds of ossicle. With the anatomical data at hand we consider the three observed specimens to belong to a single species.

S. alexandri and S. aenigma have a Central East Pacific distribution (Maluf, 1988) but are not mentioned from the Gulf of California by Maluf and Brusca (2005). The presence of $S$. challengeri along the east coast of North America up to the coast of California is putative and needs to be checked (Solís-Marin, 2003). Indeed, S. challengeri is known from sub-Antarctic islands (Théel, 1886; Massin, 1992) and the species described by Lambert (1997) as S. challengeri probably represents another species. Synallactes virgulasolida is the first Synallactes mentioned in the Gulf of California.

As in the case of many species of Mollusks and Crustacea collected in deep water along the west coast of Mexico, at the edge of the Oxygen Minimum Zone (see Hendrickx, 2001; Zamorano et al., 2006), Synallactes virgulasolida occurs in severe hypoxic conditions.

\section{ACKNOWLEDGEMENTS}

The TALUD project was supported by CONACyT (31805-N), Mexico. Ship time was granted by CTIC, UNAM. This study was supported by DGAPA, PASPA, UNAM, during a sabbatical leave of MEH at the Institut des Sciences Naturelles de Belgique (IRSNB). MEH thanks Thierry Backeljau and the IRSNB for the facilities provided during his stay. We also thank two anonymous reviewers for their useful and relevant remarks. Final edition was made by Mercedes Cordero.

\section{REFERENCES}

Cherbonnier, G. - 1988. Echinodermes: Holothurides. Faune Madag., 70: 1-292.

Clark, H.L. - 1913. Echinoderms from Lower California, with descriptions of new species. Bull. Amer. Mus. Nat. Hist., 32: 185-236.

Clark, H.L. - 1920. Holothuroidea. Report XXXII on the Scientific Results of the Expedition of the "Albatross" to the Tropical Pacific, 1899-1900 and 1904-1905. Mem. Mus. Comp. Zool., Harvard, 39 (4): 121-154.

Clark, H.L. - 1923. Echinoderms from Lower California, with de- 
scriptions of new species: Supplementary report. Bull. Amer. Mus. Nat. Hist., 48(6): 147-163.

Haney, L. - 2004. SCAMIT Meeting. SCAMIT Newsletter 23(5): 1-8, Appendix 1-4.

Hansen, B. - 1975. Systematics and Biology of the Deep-Sea Holothurians, Part 1: Elasipoda. Galathea Rep., 13: 1-262.

Hendrickx, M.E. - 2001. Occurrence of a continental slope decapod crustacean community along the edge of the minimum oxygen zone in the southeastern Gulf of California, Mexico. Belg. J. Zool., 131(2): 95-109.

Honey-Escandón, M., F.A. Solís-Marín and A. Laguarda-Figueras. - 2008. Equinodermos (Echinodermata) del Pacífico Mexicano. Rev. Biol. Trop., 56(Suppl. 3): 57-73.

Lambert, P. - 1997. Sea cucumbers of British Columbia, Southeast Alaska and Puget Sound. University of British Columbia Press, Vancouver.

Ludwig, H. - 1893. Vorlaufigen Beritch uber die auf den TiefseeFahrten des "Albatross" (Fruhling 1891) im Ostlichen Stillen Ocean erbeuteten Holothurien. Bull. Mus. Comp. Zool. Harvard Univ., 24: 105-114.

Ludwig, H. - 1894. Reports of an Exploration off the West Coasts of Mexico, Central and South America, and off the Galapagos Islands, in Charge of Alexander Agassiz, by the U.S. Fish Commission Steamer "Albatross", during 1891, Lieutenant Commander Z.L. Tanner, U.S.N., Commanding. XII. The Holothurioidea. Mem. Mus. Comp. Zool. Harvard Coll., 17(3): 1-183.

Maluf, L.I. - 1988. Composition and distribution of the Central Eastern Pacific Echinoderms. Tech. Rep., Nat. Hist. Mus. L.A. Co., 2: 1-242.

Maluf, L.I. and R.C. Brusca. - 2005. Cap. 18. Echinodermata. In: M.E. Hendrickx, R.C. Brusca and L.T. Findley (eds.), A Distributional Checklist of the Macrofauna of the Gulf of California, Mexico. Part I. Invertebrates. [Listado y Distribución de la Macrofauna del Golfo de California, México, Parte I. Invertebrados ], pp. 327-343. Arizona-Sonora Desert Museum, Tucson, $\mathrm{Az}$, . USA.

Massin, C. - 1992. Holothurians (Echinodermata) from Marion and Prince Edward Islands: new and little-known species. Zool. Scr., 21(3): 311-324.

Massin, C. - 1994. Ossicle variation in Antarctic dendrochirote holothurians (Echinodermata). Bull. Inst. R. Sc. Nat. Belg., 64: $129-146$

Massin C., A. Mercier and J.F. Hamel. - 2000. Ossicle change in Holothuria scabra with a discussion of ossicle evolution within the Holothuriidae (Echinodermata). Acta Zool., 81: 77-91.

Panning, A. - 1944. Die Trepangfischerei. Mitt. Hamburgischen Zool. Mus. Inst., 49: 2-76.

Parker, R.H. - 1964. Zoogeography and ecology of some macroinvertebrates, particularly mollusks, in the Gulf of California and the continental slope off Mexico. Vidensk. Medd. fra Dansk naturh., 126: 1-178.

Solís-Marín, F.A. - 2003. Systematics and phylogeny of the holothurian family Synallactidae. Ph.D. thesis, Univ. of Southampton.

Solís-Marín, F.A. - 2005. Synallactes laguardiae, a new species of sea cucumber from south Africa (Echinodermata: Holothuroidea: Synallactidae). Proc. Biol. Soc. Wash., 118(3): 570-575.

Solís-Marín, F.A. and A. Laguarda-Figueras. - 2004. Revision of the genus Synallactes (Echinodermata: Holothuroidea: Synallactidae). In: Heinzeller and Nebelsick (eds.), Echinoderms: Munchen, pp. 547-549. Proc. 11th Int. Echinoderm Conf., Munchen 2003, Balkema, Taylor and Francis Group.

Solís-Marín, F.A., A. Laguarda-Figueras, A. Durán-González, C.G. Ahearn and J. Torres Vega. - 2005. Echinoderms (Echinodermata) from the Gulf of California, Mexico. Rev. Biol. Trop., 53(suppl. 3): 123-137.

Thandar, A. - 1984. The holothurian fauna of southern Africa. $\mathrm{Ph}$.D. thesis, Univ. Durban-Westville.

Thandar, A. -2008 . Additions to the holothuroid fauna of the southern African temperate faunistic provinces, with descriptions of new species. Zootaxa, 1697: 1-57.

Théel, H. - 1886. Report on the Holothurioidea. Rep. Sci. Res. Challenger. Zool., 14: 1-290.

Zamorano, P., M.E. Hendrickx and A. Toledano Granados. - 2006. Distribution and ecology of deep-water mollusks from the continental slope, southeastern Gulf of California, Mexico. Mar. Biol., 150 (5): 883-892.

Scient. ed.: X. Turón.

Received October 15, 2009. Accepted January 27, 2010.

Published online June 7, 2010. 